University of Nebraska - Lincoln

DigitalCommons@University of Nebraska - Lincoln

1979

\title{
Wheat Straw and Sodium Hydroxide Treatment in Beef Cow Rations
}

C. W. Acock

College of Veterinary Medicine

J. K. Ward

Department of Animal Science

Ivan G. Rush

University of Nebraska-Lincoln, irush1@unl.edu

T. J. Klopfenstein

University of Nebraska-Lincoln, tklopfenstein1@unl.edu

Follow this and additional works at: https://digitalcommons.unl.edu/panhandleresext

Part of the Agriculture Commons

Acock, C. W.; Ward, J. K.; Rush, Ivan G.; and Klopfenstein, T. J., "Wheat Straw and Sodium Hydroxide Treatment in Beef Cow Rations" (1979). Panhandle Research and Extension Center. 17.

https://digitalcommons.unl.edu/panhandleresext/17

This Article is brought to you for free and open access by the Agricultural Research Division of IANR at DigitalCommons@University of Nebraska - Lincoln. It has been accepted for inclusion in Panhandle Research and Extension Center by an authorized administrator of DigitalCommons@University of Nebraska - Lincoln. 


\title{
WHEAT STRAW AND SODIUM HYDROXIDE TREATMENT IN BEEF COW RATIONS ${ }^{1}$
}

\author{
C. W. Acock ${ }^{2}$, J. K. Ward ${ }^{3}$, I. G. Rush ${ }^{3}$ and T. J. Klopfenstein ${ }^{3}$ \\ University of Nebraska, Lincoln 68583
}

\begin{abstract}
Summary
Two cow drylot wintering trials and a lamb digestion trial were conducted to evaluate wheat straw in maintenance diets for gestating beef cows. Wheat straw or sodium hydroxide $(\mathrm{NaOH})$ treated wheat straw, when fed ad libitum with one-third alfalfa hay, supported gestating cow weight gains equivalent to a limitfed alfalfa-bromegrass diet. Cows fed $\mathrm{NaOH}$ treated wheat straw supplemented with soybean meal and minerals gained less weight $(\mathbf{P}<.01)$ than cows on the other treatments. Calf birth weights, calving difficulty and subsequent reproductive performance of the cows were similar for all treatments. Apparent digestibility of wheat straw was increased $(P<.01)$ by $4 \%$ $\mathrm{NaOH}$ treatment in a lamb digestion trial but was not altered by balancing the sodium intake with other specific minerals. The increase in digestibility of wheat straw due to $\mathrm{NaOH}$ treatment was greater in vitro than in vivo.
\end{abstract}

(Key Words: Wheat Straw, Sodium Hydroxide, Beef Cows.)

\section{Introduction}

The increasing production costs of high quality forages and growing pressure to use grains for human consumption has stimulated interest in the use of crop residues in ruminant diets. Wheat straw is the most commonly available crop residue throughout the world and is usually produced in geographic areas where beef cows are also found.

The low digestible energy and protein content of wheat straw suggests use in diets for gestating beef cows. Dinusson (1969) concluded

\footnotetext{
${ }^{1}$ Published with the approval of the Director as Paper No. 5670 Journal Series, Nebraska Agr. Exp. Sta.

${ }^{2}$ College of Veterinary Medicine, Pullman, WA.

${ }^{3}$ Department of Animal Science.
}

from a 4-year study that two-thirds of a conventional grass-hay wintering diet for gestating beef cows could be replaced with wheat straw if supplemental protein was supplied. Alfalfa, because of its relatively high protein content, has been used to supplement cow diets composed primarily of straw (McKee et al., 1977; Hackett et al., 1975; Maeng et al., 1971). Other research indicates that gestating beef cows can be wintered with wheat straw alone if they can with. stand moderate weight loss (Arnett and Mc. Chord, 1927; Taylor et al., 1977).

To meet the energy requirement of a gestating beef cow with only wheat straw it would be necessary to increase straw digestibility. Recent reviews by Klopfenstein (1978) and Jackson (1977) indicate that treatment with sodium hydroxide $(\mathrm{NaOH})$ will increase digestibility of wheat straw. The objectives of this study were to measure the performance of gestating beef cows on diets containing wheat straw and to evaluate the effect of $\mathrm{NaOH}$ treatment of the straw.

\section{Experimental Procedure}

Trial 1. Eighty mature crossbred (Angus $x$ Hereford) cows were randomly assigned to four dietary treatments (table 1) with two replications of 10 cows per treatment. Cows weighed $509 \mathrm{~kg}$ and were in mid-gestation at the start of the trial conducted during the winter of $1976-$ 77.

Wheat straw, for treatments 3 and 4, was treated with $4 \% \mathrm{NaOH}$ on a dry matter (DM) basis 20 days before the initiation of the trial. Straw was chopped to a length of approximately $4 \mathrm{~cm}$ and brought to about $50 \%$ moisture. $\mathrm{NaOH}$ was added to supply $4 \mathrm{~g} \mathrm{NaOH} / 100 \mathrm{~g}$ $D M$ in a manner similar to the spray treatment of Wilson and Pidgen (1964). The treated straw was stored in a bunker silo. Chopped alfalfa was mixed with $\mathrm{NaOH}$ treated straw at feeding time for treatment 3 , while treatment 4 consisted of a soybean meal (SBM)-mineral supplement 
TABLE 1. DIET COMPOSITION FOR COW TRIAL 1

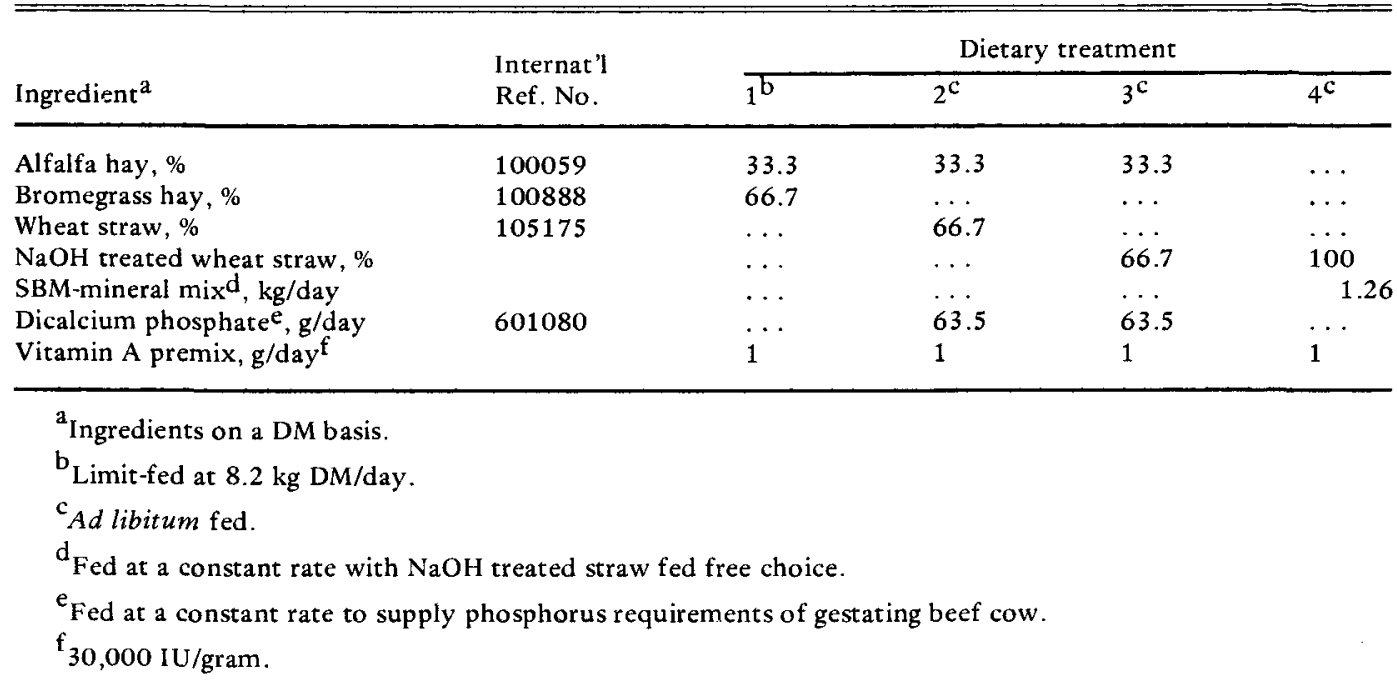

addition to treated wheat straw (tables 2 and 3).

Supplement for treatment 4 (table 2) was formulated to supply the NRC (1976) suggested crude protein (CP) requirement for a $500 \mathrm{~kg}$ gestating beef cow. Minerals were added to the SBM based supplement to overcome mineral imbalance that may occur from high intakes of sodium (Moseley and Jones, 1974). Mineral ratios, as described by Lesoing (1977), were maintained. This supplement was fed at a constant rate of $1.26 \mathrm{~kg} /$ day with $\mathrm{NaOH}$ treated wheat straw fed ad libitum for treatment 4.

The trial consisted of a 100-day winter drylot feeding program and an additional 5 days

TABLE 2. COMPOSITION OF SBM-MINERAL MIX FOR COW TRIAL $1^{\text {a }}$

\begin{tabular}{lc}
\hline Ingredient & \% of DM \\
\hline SBM & 74.49 \\
Potassium chloride & 9.23 \\
Limestone & 9.17 \\
Dicalcium phosphate & 4.76 \\
Magnesium oxide & 2.06 \\
Trace mineral premix & $\mathrm{b}$ \\
\end{tabular}

${ }^{a_{1}}{ }_{1.26} \mathrm{~kg} \mathrm{DM} \mathrm{fed} / \mathrm{hd} / \mathrm{day}$. Formulated to supply $.93 \mathrm{~kg} \mathrm{SBM} / \mathrm{hd} /$ day, . $30 \% \mathrm{P}$ and the following ratios of minerals: $\mathrm{Na}: \mathrm{k}, 1: 1 ; \mathrm{Na}: \mathrm{Ca}, 2: 1 ; \mathrm{Na}: \mathrm{Mg}, 6: 1 ; \mathrm{Na}: \mathrm{Cl}$, 1.7:1.

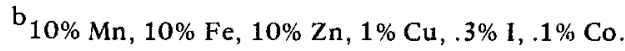

where all cows received $6.7 \mathrm{~kg}$ of corn silage on a DM basis. This additional 5 days was to equalize rumen fill due to different rates of digestion and water consumption for diet treatments. Initial, 100-day and 105-day weights were obtained after holding animals without feed and water for 16 hours. Average daily gain (ADG), daily feed intake and gain to feed ratios were calculated. Calf birth weights and calving difficulty were observed and subsequent reproductive performance was evaluated.

Trial 2. Trial 2 was conducted the winter of 1977-78 with a design similar to trial 1. Eighty crossbred cows weighing $490 \mathrm{~kg}$ were assigned to the four treatments shown in trial 1 except $1.38 \mathrm{~kg}$ of a reformulated SBM-mineral mix

TABLE 3. COMPOSITION OF SBM-MINERAL MIX FOR COW TRIAL $2^{\mathrm{a}}$

\begin{tabular}{lc}
\hline Ingredient & \% of DM \\
\hline SBM & 67.36 \\
Potassium chloride & 13.56 \\
Limestone & 10.78 \\
Dicalcium phosphate & 5.60 \\
Magnesium oxide & 2.36 \\
Trace mineral premix & b \\
\hline
\end{tabular}

${ }^{a} 1.38 \mathrm{~kg} \mathrm{DM}$ fed/hd/day. Formulated to supply $.93 \mathrm{~kg} \mathrm{SBM} / \mathrm{hd} / \mathrm{day}, .30 \% \mathrm{P}$ and the following ratios of minerals: $\mathrm{Na}: \mathrm{K}, 1: 1 ; \mathrm{Na}: \mathrm{Ca}, 2: 1 ; \mathrm{Na}: \mathrm{Mg}, 6: 1 ; \mathrm{Na}: \mathrm{Cl}$, $1.7: 1$.

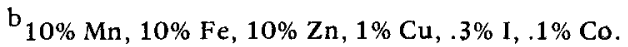


(table 3) was fed to each cow that received treatment 4 . The new supplement was formulated to supply additional minerals to maintain the ratios described for trial 1 without increasing protein supplementation. This was necessary in anticipation of an increased intake of $\mathrm{NaOH}$ treated straw resulting in a larger intake of sodium.

$\mathrm{NaOH}$ treatment was performed on a weekly basis to eliminate heating and spoilage of the straw that had occurred during storage in trial 1. For trial 2, wheat straw was chopped as described in trial 1 , weighed into a mixer wagon, brought to about $50 \%$ moisture and dry $\mathrm{NaOH}$ was added to supply $4 \mathrm{~g} \mathrm{NaOH} / 100 \mathrm{~g}$ straw DM. After thorough mixing, treated straw was allowed to react for $24 \mathrm{hr}$ before feeding. Procedures for feeding, weighing and performance evaluations were the same as trial 1 .

Statistical analysis of trials 1 and 2 was conducted according to analysis of variance procedure outlined by Steel and Torrie (1960). Orthogonal comparisons were performed to evaluate treatment differences for ADG. These two trials were then pooled and analyzed to further evaluate treatment differences.

Trial 3. A lamb digestion trial was conducted to evaluate $\mathrm{NaOH}$ treatment of wheat straw. Twenty-four crossbred wether lambs were assigned to six treatments (table 4 ) in a completely randomized design. Lambs were housed in digestion stalls and fitted with canvas fecal collection bags.

Forages were ground through a $1.3 \mathrm{~cm}$ screen with particle length generally from $1 /$ : to $2 \mathrm{~cm}$ and mixed prior to a daily feeding $\mathrm{NaOH}$ treatment of wheat straw was similar tc cow trial 2. Treated material was packed in 20 s liter barrels and allowed to react for $48 \mathrm{hr}$ be fore feeding. Treatments $1,2,3$ and 4 were sup plemented with $6.2 \mathrm{~g}$ of monosodium phos phate to insure adequate phosphorus. Fou grams of salt daily were added to treatments 1 2 and 3. All lambs were given 30,000 IU of vita tim A 2 days prior to the collection period Lambs were prefed ad libitum for 11 days anc then restricted to $600 \mathrm{~g}$ DM per day for at additional 3 days. Daily grab samples of all for ages were taken and stored for subsequen analyses. At the end of this 14-day prefeeding period a 7-day total fecal collection was initi ated. Lambs were reallotted and again prefer before a second 7-day fecal collection period.

Total fecal collection for each lamb wa composited and frozen until subsamples coulc be taken for DM, organic matter (OM) and $\mathrm{CI}$ analyses. Feed refusal was weighed daily anc sampled for subsequent analyses. DM was ob tained by drying for $48 \mathrm{hr}$ at $65 \mathrm{C}$ and then 2 , hr at $105 \mathrm{C}$ in a forced air oven. OM percentag. on a DM basis was calculated by subtractin! $\mathrm{DM}$ ash percentage ( $600 \mathrm{C}$ for $3 \mathrm{hr}$ ) from 100 Protein determinations were performed on : wet sample using the Kjeldahl method (AOAC

TABLE 4. DIET COMPOSITION FOR LAMB DIGESTION STUDY

\begin{tabular}{|c|c|c|c|c|c|c|c|}
\hline \multirow[b]{2}{*}{ Ingredient ${ }^{\mathrm{a}}$} & \multirow{2}{*}{$\begin{array}{l}\text { Internat'l } \\
\text { Ref. No. }\end{array}$} & \multicolumn{6}{|c|}{ Dietary treatment } \\
\hline & & 1 & 2 & 3 & 4 & 5 & $6^{\mathrm{d}}$ \\
\hline & & \multicolumn{6}{|c|}{$(\%)$} \\
\hline Alfalfa hay & 100059 & 100 & 33.33 & 33.33 & 33.33 & $\ldots$ & $\ldots$ \\
\hline Bromegrass hay & 100888 & $\ldots$ & 66.67 & $\cdots$ & .. & $\ldots$ & $\cdots$ \\
\hline Wheat straw & 105175 & $\ldots$ & $\ldots$ & 66.67 & $\ldots$ & $\ldots$ & $\ldots$ \\
\hline $\mathrm{NaOH}$ treated wheat straw $b$ & & .. & $\ldots$ & $\ldots$ & 66.67 & 89.08 & 84.36 \\
\hline SBM & & $\ldots$ & $\ldots$ & $\ldots$ & $\ldots$ & 10.10 & 10.64 \\
\hline Dicalcium phosphate ${ }^{c}$ & 601080 & $\ldots$ & .. & $\ldots$ & $\ldots$ & .82 & .83 \\
\hline Potassium chloride & & $\ldots$ & $\ldots$ & $\ldots$ & $\ldots$ & $\ldots$ & 1.92 \\
\hline Magnesium oxide & & $\ldots$ & $\ldots$ & $\ldots$ & $\ldots$ & $\ldots$ & .36 \\
\hline Limestone & & $\ldots$ & $\ldots$ & $\ldots$ & $\ldots$ & $\ldots$ & 1.73 \\
\hline Trace mineral premix & & $\ldots$ & $\ldots$ & $\ldots$ & $\therefore$ & $\ldots$ & .05 \\
\hline Percentage CP & & 17.5 & 13.6 & 8.9 & 8.4 & 8.9 & 8.9 \\
\hline
\end{tabular}

\footnotetext{
${ }^{a}$ Ingredients on a DM basis.

$\mathrm{b}_{4} \mathrm{~g} \mathrm{NaOH} / 100 \mathrm{~g}$ straw.

Co supply .30\% $\mathrm{P}$ in the diet.

${ }^{d}$ Minerals added to supply the following ratios: $\mathrm{Na}: \mathrm{K}, 1: 1 ; \mathrm{Na}: \mathrm{Ca}, 2: 1 ; \mathrm{Na}: \mathrm{Mg}, 6: 1 ; \mathrm{Na}: \mathrm{Cl}, 1.7: 1$.
} 
1970). In vitro $\mathrm{DM}$ digestibility and in vitro $\mathrm{OM}$ disappearance was obtained using the Moore modification of the two-stage Tilley-Terry procedure as reported by Harris (1970). This procedure was further modified by using a rumen fluid to buffer ratio of 30:70. One gram of urea was added per liter of buffer before rumen fluid addition. Analysis of variance and orthogonal comparisons as described by Steel and Torrie (1960) were performed on these parameters.

\section{Results}

Trials 1 and 2. Cows fed $\mathrm{NaOH}$ treated wheat straw supplemented with a SBM-mineral mix gained less weight $(P<.05)$ than did cows fed the other three diets (table 5). When treated or untreated wheat straw was mixed with alfalfa hay (treatments 2 and 3) and fed ad libitum cows gained as much weight as the limitfed control diet composed of alfalfa and bromegrass hays. These data are in agreement with Dinusson (1969) who concluded that up to two-thirds of a conventional beef cow hay diet could be successfully replaced with wheat straw while maintaining adequate performance and minimizing possibilities for rumen compaction.

Research has shown that $\mathrm{NaOH}$ treatment of wheat straw will increase intake (Klopfenstein, 1978). In this trial due to spoilage observed as heating and mold growth, $\mathrm{NaOH}$ treated wheat straw intake was lower $(10.0 \mathrm{~kg}$ daily in treatment 3) than for untreated straw (11.8 kg daily in treatment 2). Although consumption was 1.8 $\mathrm{kg}$ higher for the untreated straw treatment, daily gain and gain to feed ratios favored the two-thirds treated straw diet.

Switching all treatments to corn silage for 5 days after the 100-day dietary treatment period reduced apparent ADG. When comparing 100day and 105-day ADG the apparent reduction was $.10, .08, .10$ and $.06 \mathrm{~kg}$ daily for treatments $1,2,3$ and 4 , respectively. This observation suggests that at the 100 -day weighing cows had a considerable amount of rumen fill even after being held without feed and water for 16 hours. Feeding corn silage, which is more rapidly digested, gave a better measure of actual cow weight change over the feeding period by eliminating a portion of the rumen fill differences.

There were no differences in subsequent calving difficulty or calf birth weight for the four winter-diets. Reproductive performance was satisfactory with no differences associated with the feeding of wheat straw.
Performance of cows on all treatments in trial 2 was not as good as in trial 1 (table 5) which may have been due to the severity of the weather during trial 2 . There were no significant differences in 105-day ADG with 105-day gains being lower than were observed in trial 1 (table 5). Cows fed $\mathrm{NaOH}$ treated wheat straw supplemented with the SBM-mineral mix tended to gain slightly less weight, but with some improvement in feed efficiency. Treatment of straw tended to improve performance when fed with alfalfa as had been seen in trial 1. In this experiment the limit-fed alfalfa bromegrass hay treatment appeared to support greater weight gains than the two-thirds wheat straw diets.

Weekly $\mathrm{NaOH}$ treatment of wheat straw to eliminate spoilage in storage appeared to improve consumption of treated straw over that observed in trial 1 . In this trial, cows fed $\mathrm{NaOH}$ treated wheat straw with alfalfa consumed 12.4 $\mathrm{kg}$ of DM compared to $10.9 \mathrm{~kg}$ of untreated straw and alfalfa. The increased intake did not further increase gains for the alfalfa and treated straw treatment. This may be because of a decrease in digestibility due to increased intake or a higher sodium intake from $\mathrm{NaOH}$ treated straw as observed by Berger (1978).

Feeding corn silage for 5 days reduced apparent ADG for treatments $1,2,3$ and 4 by $.04, .18, .07$ and $.05 \mathrm{~kg}$, respectively. The reduction in apparent ADG for treatment 2 was much larger than the other treatments. This observation suggests that more rumen fill existed for cows fed untreated wheat straw at the 100-day weighing because of its slower rate of digestion.

Calf birth weights for treatments 1, 2, 3 and 4 were $35.6,35.2,36.3$ and $37.6 \mathrm{~kg}$, respectively, however, differences were not significant. Calving difficulty was similar for all treatments. Reproductive performance was not altered by the winter dietary treatments.

Trials 1 and 2 (pooled). Since trial 1 and 2 had identical experimental designs and similar treatments they were pooled for statistical analyses (table 6 ). These analyses show a lower $(\mathrm{P}<.01) \quad 100$-day and 105-day ADG for cows that received treated straw supplemented with SBM and minerals. This lower performance may have resulted from high sodium intake from the $\mathrm{NaOH}$ treatments (Berger, 1978; Paterson et al., 1978) or from a lower protein content of the diet. All treatments exceeded the minimum level of protein suggested by NRC (1976), how- 
ACOCK ET AL.

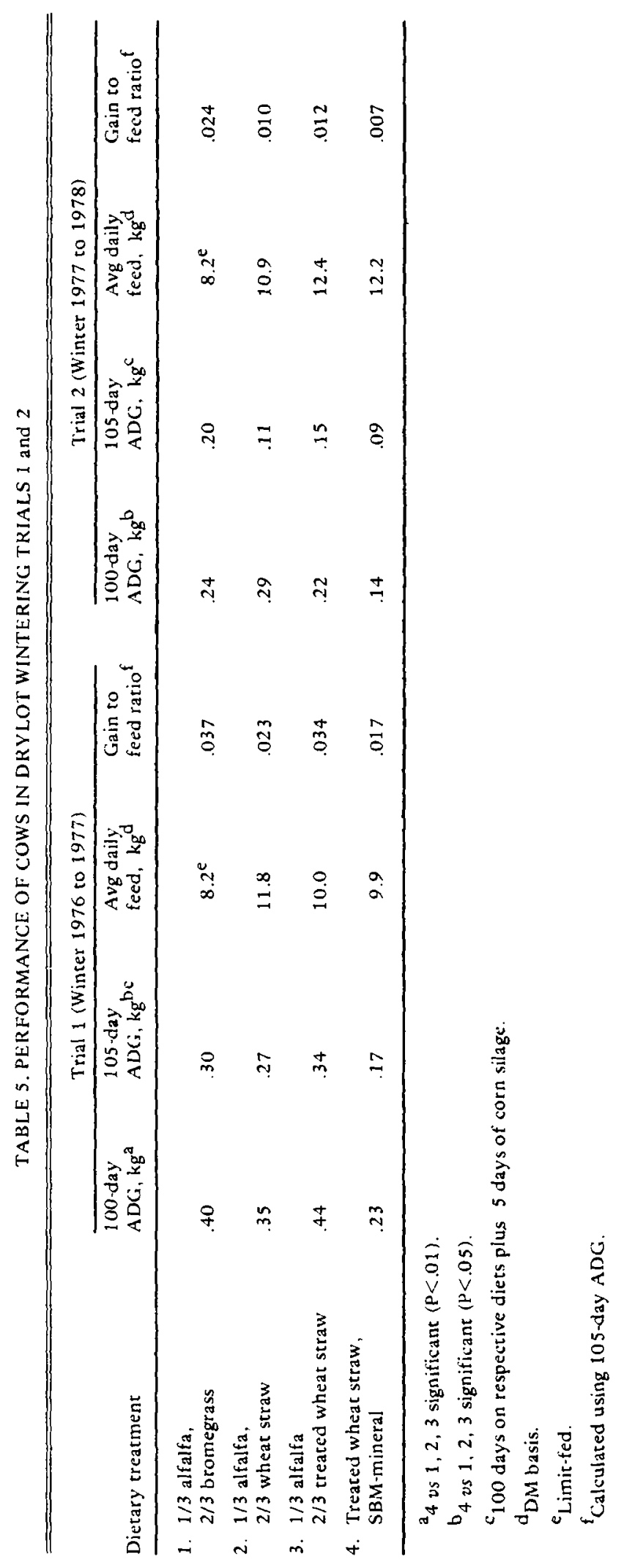


TABLE 6. PERFORMANCE OF COWS IN DRYLOT COW WINTER TRIALS 2-YEAR AVERAGE

\begin{tabular}{|c|c|c|c|c|}
\hline Dietary treatment & $\begin{array}{l}\text { 100-day } \\
\text { ADG, } \mathrm{kg}^{\mathrm{a}}\end{array}$ & $\begin{array}{l}\text { 105-day } \\
\text { ADG, kg bc }\end{array}$ & $\begin{array}{l}\text { Avg daily } \\
\text { feed, kg }\end{array}$ & $\begin{array}{l}\text { Gain to } \\
\text { feed ratio }\end{array}$ \\
\hline $\begin{array}{l}\text { 1. } 1 / 3 \text { alfalfa, } \\
2 / 3 \text { bromegrass }\end{array}$ & .32 & .25 & 8.2 & .030 \\
\hline $\begin{array}{l}\text { 2. } 1 / 3 \text { alfalfa, } \\
2 / 3 \text { wheat straw }\end{array}$ & .32 & .19 & 11.4 & .017 \\
\hline $\begin{array}{l}\text { 3. } 1 / 3 \text { alfalfa, } \\
2 / 3 \text { treated wheat straw }\end{array}$ & .33 & .25 & 11.2 & .022 \\
\hline $\begin{array}{l}\text { 4. Treated wheat straw, } \\
\text { SBM-mineral }\end{array}$ & .19 & .13 & 11.1 & .012 \\
\hline
\end{tabular}

\footnotetext{
$\mathrm{a}_{4}$ vs $1,2,3$ significant $(\mathrm{P}<.01)$.

$\mathrm{b}_{4}$ vs $1,2,3$ significant $(\mathrm{P}<.01) ; 2$ vs 3 significant $(\mathrm{P}<.10)$.

$\mathrm{c}_{100}$ days on respective diets plus 5 days of corn silage.

$\mathrm{d}_{\text {DM basis. }}$

'Limit-fed.

$f_{\text {Calculated using 105-day ADG. }}$
}

ever, treatment 4 was slightly below the minimum suggested by Church (1977). The direct comparison of $\mathrm{NaOH}$ treated straw and untreated straw when fed with alfalfa (treatments 2 and 3$)$ showed an advantage $(\mathrm{P}<.10)$ for the $\mathrm{NaOH}$ treated straw when 105-day ADG was calculated.
Trial 3. Apparent dry matter digestibility (DMD) and organic matter digestibility (OMD) of wheat straw in lambs was increased $(\mathrm{P}<.01)$ by $4 \% \mathrm{NaOH}$ treatment (table 7 ). When $\mathrm{NaOH}$ treated straw was fed with alfalfa, a lower $(\mathrm{P}<.01)$ apparent nitrogen digestibility (ND) resulted when compared to untreated straw and

TABLE 7. DIGESTIBILITY COEFFICIENTS FOR LAMB DIGESTION STUDY

\begin{tabular}{|c|c|c|c|c|}
\hline Dietary treatment & $\begin{array}{l}\text { Daily } \\
\text { intake, } \mathrm{g}^{\mathrm{a}}\end{array}$ & $\mathrm{DMD}^{\mathrm{b}}$ & $\mathrm{OMD}^{\mathrm{b}}$ & $N D^{b c}$ \\
\hline & & & $-(\%)$ & \\
\hline 1. Alfalfa hay & 590.1 & 49.5 & 50.3 & 68.5 \\
\hline $\begin{array}{l}\text { 2. } 1 / 3 \text { alfalfa, } \\
2 / 3 \text { bromegrass }\end{array}$ & 594.4 & 55.2 & 56.9 & 60.9 \\
\hline $\begin{array}{l}\text { 3. } 1 / 3 \text { alfalfa, } \\
2 / 3 \text { wheat straw }\end{array}$ & 496.7 & 47.8 & 50.2 & 56.0 \\
\hline $\begin{array}{l}\text { 4. } 1 / 3 \text { alfalfa, } 2 / 3 \\
\text { treated wheat straw }\end{array}$ & 579.3 & 55.7 & 56.6 & 51.8 \\
\hline $\begin{array}{l}\text { 5. Treated wheat straw, } \\
\text { soybean meal }\end{array}$ & 581.6 & 62.6 & 63.7 & 60.6 \\
\hline $\begin{array}{l}\text { 6. Treated wheat straw, } \\
\text { SBM-mineral }\end{array}$ & 593.4 & 61.3 & 61.8 & 58.7 \\
\hline
\end{tabular}

${ }^{\mathrm{a}} \mathrm{DM}$ basis, all lambs were offered $600 \mathrm{~g} \mathrm{DM} / \mathrm{day}$.

$\mathrm{b}_{1}$ vs $2,3,4,5,6 ; 3,4$ vs 5,$6 ; 3$ vs 4 significant $(\mathrm{P}<.01)$.

$\mathrm{c}_{2}$ vs $3,4,5,6$ significant $(\mathrm{P}<.01)$. 
alfalfa. Alfalfa hay had the highest ND $(\mathrm{P}<.01)$.

A relatively low OMD value was obtained for the alfalfa hay treatment when compared to the other treatments. This observation may have been due to a slower rate-of-passage for the straw diets and higher than expected digestibility of these diets. Also, the alfalfa used was mature with a low leaf-to-stem ratio. Intake of the untreated straw diet was lower than the 600 $\mathrm{g}$ offered which may have been an advantage due to lowered intake and rate of passage (Lesoing, 1977).

Assuming the OMD of the one-third portion of alfalfa hay in treatments 2 and 4 as determined by difference to be the same as the all alfalfa diet, digestibility for untreated and treated straw was 50.1 and $59.7 \%$, respectively. In vitro $\mathrm{OM}$ for $4 \% \mathrm{NaOH}$ treated wheat straw was $62.7 \%$. The somewhat higher in vitro than in vivo digestibility is in agreement with other research (Rexen and Thomsen, 1976; Levy et al., 1977; Berger, 1978).

Addition of supplemental minerals to the $\mathrm{NaOH}$ treated wheat straw diet did not alter DMD, OMD or ND. This observation agrees with work by Paterson et al. (1978) who showed little change in digestibility when minerals were added to $\mathrm{NaOH}$ treated corn cob diets. An improvement in the metabolic balance of these minerals may occur (Paterson et al., 1978) that could account for an improvement in performance observed by Lesoing (1977) in growing calves.

\section{Literature Cited}

AOAC. 1970. Official Methods of Analysis (11th Ed.). Association of Analytical Chemists, Washington, DC.

Arnett, C. N. and R. C. McChord. 1927. Winter feeding beef breeding cows. Univ. of Montana Agr. Exp. Sta. Bull. No. 211.

Berger, Larry L. 1978. Effect of harvest date and sodium hydroxide treatment on corn plant residue utilization by ruminants. Ph.D. Dissertation. Univ. of Nebraska, Lincoln.

Church, D. C. 1977. Livestock Feeds and Feeding. 0 and B Book. Corvallis, OR.

Dinusson, W. E. 1969. 20th Annual Research Roundup. Dickinson Exp. Sta., Dickinson, ND.

Hackett, M. R., J. K. Hillers, R. P. Kromann and E. L. Martin. 1975. Evaluation of wheat straw in feeder lamb rations. Proc. West. Sec. ASAS 26: 234.

Harris, L. E. 1970. Nutrition Research Techniques for Domestic and Wild Animals. Volume 1. Published by L. E. Harris, Logan, UT.

Jackson, M. G. 1977. Review article: The alkali treatment of straws. Anim. Feed Sci. Technol. 21 : 105.

Klopfenstein, Terry. 1978. Chemical treatment of crop residues. J. Anim. Sci. 46:841.

Lesoing, G. W. 1977. Chemical treatment of wheat straw. M.S. Thesis. Univ. of Nebraska, Lincon.

Levy, D., Z. Holzer, H. Neumark and Y. Folman. 1977. Chemical processing of wheat straw and cotton by-products for fattening catcle. I. Performance of animals receiving the wet material shortly after treatment. Anim. Prod. 25:27

Maeng, W. J., D. N. Mowat and W. K. Bilanski. 1971. Digestibility of $\mathrm{NaOH}$-treated straw fed alone or in combination with alfalfa silage. Can. J. Anim. Sci. $51: 743$.

McKee, M., K. G. Kimple and Keith Bolsen. 1977. Crop residues for wintering cows in drylot. J. Anim. Sci. 45(Suppl. 1): 123 .

Moseley, G. and D. I. H. Jones. 1974. The effect of sodium chloride supplementation of a sodium adequate hay on digestion, production and mineral nutrition in sheep. J. Agr. Sci. 83:37.

NRC. 1976. Nutrient Requirements of Beef Cattle, Nutrient Requirements of Domestic Animals, No. 4. National Academy of Sciences - National Research Council, Washington, DC.

Paterson, J. A., T. K. Klopfenstein and R. A. Britton. 1978. Effect of sodium hydroxide treatments of roughage on mineral balance and digestibility. J. Anim. Sci. 47(Suppl. 1): 433 .

Rexen, F. and K. V. Thomsen. 1976. The effect on digestibility of a new technique for alkali treatment of straw. Anim. Feed Sci. Technol. 1:73.

Steel, R. G. D. and J. H. Torrie. 1960. Principles and Procedures of Statistics. McGraw-Hill Book Co., New York.

Taylor, B., M. Selke and W. H. Hale. 1977. Drylot cow-calf research - utilization of low quality roughages in maintaining beef cows. Arizona Cattle Feeder's Day, Univ. of Arizona Agr. Exp. Sta. Anim. Sci. Dept.

Wilson, R. K. and W. J. Pidgen. 1964. Effect of sodium hydroxide treatment on the utilization of wheat straw and poplar wood by rumen microorganisms. Can. J. Anim. Sci. 44:123. 